\title{
Effects of Temperature and Water Vapor Pressure on Conidial Germination and Lesion Expansion of Sphaerotheca macularis f. sp. fragariae
}

\author{
T. C. Miller and W. D. Gubler, Department of Plant Pathology, S. Geng, Department of Agronomy and Range Sci- \\ ence, and D. M. Rizzo, Department of Plant Pathology, University of California, Davis 95616
}

\begin{abstract}
Miller, T. C., Gubler, W. D., Geng, S., and Rizzo, D. M. 2003. Effects of temperature and water vapor pressure on conidial germination and lesion expansion of Sphaerotheca macularis f. sp. fragariae. Plant Dis. 87:484-492.

Conidial germination in vitro and foliar lesion expansion were studied for Sphaerotheca macularis $\mathrm{f}$. sp. fragariae. Detached strawberry (Fragaria $\times$ ananassa) leaves were inoculated, then held in controlled environments of constant temperatures $\left(4\right.$ to $\left.36^{\circ} \mathrm{C}\right)$ and relative humidity (RH, 32 to $100 \%$ ) representing the range of these variables observed under California commercial production conditions. Percent germination and lesion expansion rate were determined by destructive subsampling over time. Conidia germinated at all temperatures by $6 \mathrm{~h}$ and reached a maximum by $48 \mathrm{~h}$, with the optimum near $20^{\circ} \mathrm{C}$. Lesions were marked with the aid of a microscope and measured by computer-assisted image-analysis to determine expansion rate. Maximal rates occurred at $25^{\circ} \mathrm{C}$. Several growth models were fit to the expansion rate data with high significance. Predicted optima from these models ranged from 22 to $27^{\circ} \mathrm{C}$ and/or 17 to $27 \mathrm{~mm}$ $\mathrm{Hg} \mathrm{VP}_{\text {water } @ 100 \% \mathrm{RH}}$. Neither $\mathrm{RH}$, partial vapor pressure of water $\left(\mathrm{VP}_{\text {water }}\right)$, nor vapor pressure deficit (VPD) correlated with lesion expansion rate, adding to studies minimizing the importance of RH and VPD as determinants of asexual phase powdery mildew growth other than specifically at spore germination.
\end{abstract}

Loss of fruit quality and quantity subsequent to high levels of foliar, floral, and fruit infection by the fungus Sphaerotheca macularis (Wallr. ex Frier) Cooke f. sp. fragariae encourages regular use of fungicides on roughly half $(>5,000 \mathrm{ha})$ the fresh strawberry (Fragaria $\times$ ananassa) production in California, predominantly in coastal regions. Disease management options include transplanting clean, resistant cultivars and topical application of fungicidal compounds. According to the National Agricultural Statistics Service (NASS) of the U.S. Department of Agriculture (USDA), more than $164,000 \mathrm{~kg}$ of fungicides were used in chemical control of strawberry powdery mildew in 2000 in the United States. Current management with topical therapies relies upon applications of fungicides at 7- to 21-day intervals throughout the fruit production season, based upon length of residual activity and weather-fastness of materials applied.

Interaction of environmental factors with pathogen growth were poorly understood. Conflicting reports from different researchers (see discussion) with respect to this pathogen suggest geographic variants

Corresponding author: T. C. Miller

E-mail: tcmiller@ucdavis.edu

Accepted for publication 24 November 2002.

Publication no. D-2003-0221-01R

(C) 2003 The American Phytopathological Society in the global population. Cardinal temperature studies for conidial germination had been reported as early as 1900 (34), with thorough reviews six decades later $(16,30)$. Water relations were investigated with respect to conidial germination and growth in the 1960s $(16-18,30)$. Disease progress curves and coincidental weather were tracked in the 1970s (19) and 1980s (20), yet prior to the present study, none had quantified lesion expansion rate as influenced by factors of weather. Also, spore dehiscence and release remains undescribed for this pathogen, although initial data on inoculum potential of sporulating lesions as a function of temperature has been gathered (21). The requirement for near-saturated air for conidial germination $(16,30)$ was possibly unduly influential upon research to understand lesion development and sporulation. Furthermore, the known detrimental effects of free water upon other powdery mildews (47) do not pertain in the case of the strawberry mildew (17), which might give a false sense of security following rainfall. The lack of understanding was evident by growers' (and researchers') inability to consistently define "powdery mildew weather" for this pathogen, let alone keep the disease in check using weather as a guide to fungicide applications. We initiated controlled studies to define weather conditions conducive to powdery mildew growth, to more efficiently apply fungicidal treatments on strawberries. Simultaneously, we collected weather data and disease progress curves
(21) from sites throughout California strawberry fields.

Quick visual inspection of apparently healthy strawberry foliage usually misses strawberry powdery mildew infections in the latent phase of the disease cycle. Microscopic examination of the lower surface of strawberry leaves from production fields often revealed the presence of the pathogen and near-total abaxial surface infection, although the fungus was invisible to the unaided eye when not sporulating. Visible sporulation of the pathogen often surprised growers who had been unaware of the steady increase of unseen lesions across the leaf surface. We felt this fungal growth might be described as a response to the environmental variables of temperature and $\mathrm{RH}$ (and therein, water vapor pressure and its deficit).

Unprecedented lesion expansion rate data for this pathogen were collected by varying temperature and $\mathrm{RH}$, while holding light, irrigation, and host and pathogen ages constant. Since in vitro germination requires humidity near saturation (17), only temperature was studied over time. These studies add new factors to critical evaluations concerning strawberry mildew epidemiology by Peries (29-31), Jhooty and McKeen (15-18), our laboratory (21$26)$, and others $(20,34,37)$. Our objective was to describe some factors of pathogen growth and resulting disease development as a function of temperature and $\mathrm{RH}$ by using measurements of spore germination and lesion expansion rate in controlled environments.

\section{MATERIALS AND METHODS}

Inoculation procedure. Each inoculation employed a vacuum-operated settling tower (33) and a single tower inoculation event to assure random distribution of an equal number of spores throughout the replicates used in each experiment. Inoculum density averaged $50 \pm 25$ conidia per $\mathrm{cm}^{2}$. Inoculum was brushed with an artists' paint brush from sporulating lesions onto an inoculation stage within the tower, then dispersed (by sudden release of accumulated vacuum pressure within the tower) to settle as individual conidia. A continuous source of inoculum for powdery mildew was provided by serial passage on strawberry (Fragaria $\times$ ananassa, cultivars Selva, Sunset, Camarosa, and Pajaro) plants in greenhouse and growth chambers. The original infected host collection from 
Watsonville, CA, was inoculated by directly rubbing collected leaves with sporulating lesions against potted strawberry plants in the greenhouse, from which a single conidium from a resulting lesion was used to establish the source. Isolates were maintained by serial inoculations (every 3 to 5 weeks) of container-grown strawberry plants maintained in growth chambers.

Germination experiments. Young conidia from 10- to 30-day-old colonies on 3to 8-week-old strawberry plants, cv. Sunset, were allowed to settle onto microscope slide coverslips $(22 \times 22 \mathrm{~mm})$. The coverslips were then placed on platforms over water in glass humidifiers (desiccators with water in place of a drying agent). Three sealed vessels were placed in incubators maintained at a constant temperature of $4,15,21,25,30$, or $36 \pm 0.5^{\circ} \mathrm{C}$ in the dark. Internal chamber conditions were monitored by use of Hobo temperature and
RH sensors (Onset Computer Corp., Pocasset, MA). At eight intervals $(6,20,48$, $96,144,192,240$, and $288 \pm 0.1 \mathrm{~h}$ ) over 12 days the chambers were opened briefly to remove three replicate coverslips (1 per chamber; $n=3 \times 48=144$ ). Temperatures reported are means of three replicated chambers. The experimental design was balanced, lending itself to analysis of variance as a completely randomized design (CRD) at each point in time.

After fixing subsamples (inoculated coverslips removed at intervals given) immediately in lactophenol-cotton blue (6) to arrest further development, germination percentage was determined by microscopic examination of at least 300 spores per coverslip ( $n>4.32 \times 10^{4}$ spores). To standardize the measure, conidia were scored as germinated when their germ tube(s) exceeded their lateral radius, as suggested by the APS Committee on Standardization of Fungicidal Tests (38).

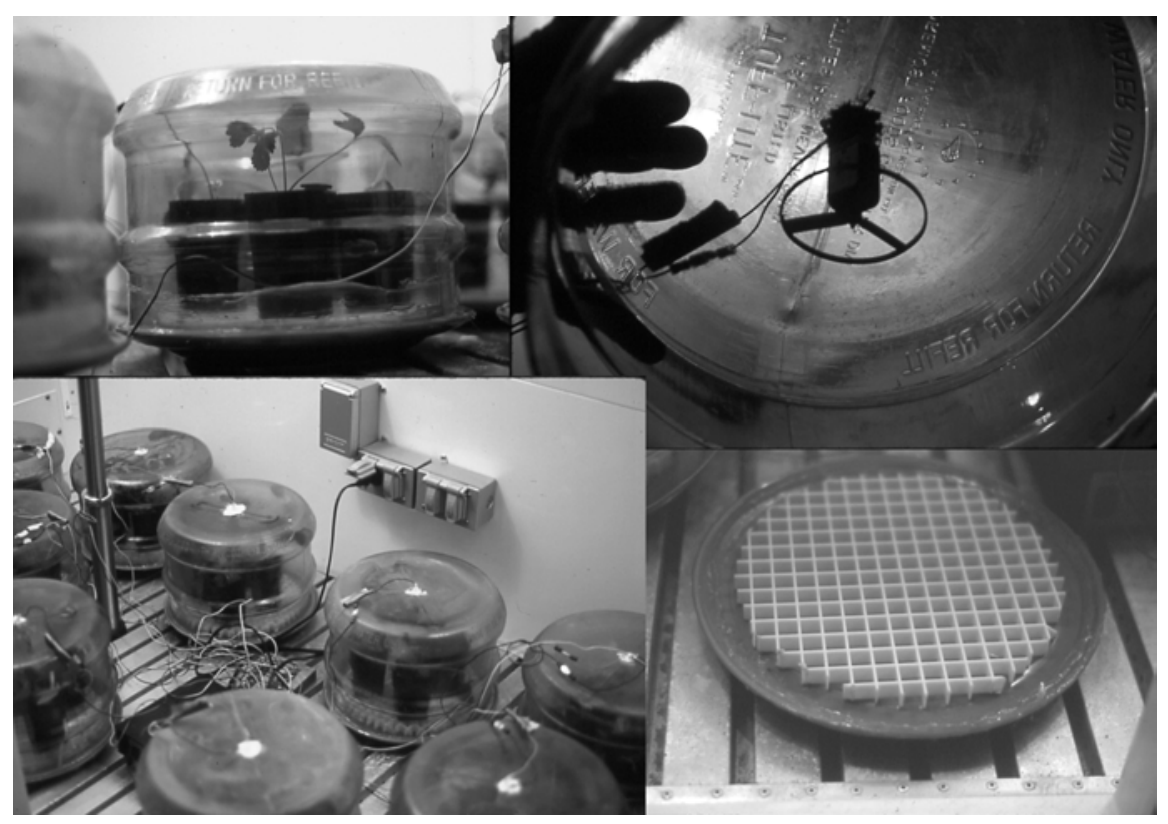

Fig. 1. Controlled environments for studying pathogen biology. Host-pathogen interaction as affected by temperature, relative humidity, water vapor pressure, and its deficit was monitored in closed environments containing saturated-salt solutions. Details of solutions and chamber construction in text. Clockwise from upper left: side view of mini-chamber, internal fan to provide air mixing within mini-chamber, grid platform spanning plate holding saturated-salt solution, and large Conviron chamber containing 12 mini-chambers.

Table 1. Saturated-salt solutions used and relative humidities as measured in chamber studies (and literature reference values)

\begin{tabular}{cccccc}
\hline Temp. ${ }^{\mathbf{a}}\left({ }^{\circ} \mathbf{C}\right)$ & $\mathbf{M g C l}_{\mathbf{2}} \cdot \mathbf{6} \mathbf{H}_{\mathbf{2}} \mathbf{O}$ & $\mathbf{M g}\left(\mathbf{N O}_{\mathbf{3}}\right)_{\mathbf{2}} \cdot \mathbf{6} \mathbf{H}_{\mathbf{2}} \mathbf{O}$ & $\mathbf{N H}_{\mathbf{4}} \mathbf{N O}_{\mathbf{3}}$ & $\mathbf{K C l}$ & $\mathbf{H}_{\mathbf{2}} \mathbf{O}$ \\
\hline 5 & $40.1^{\mathrm{b}}\left(33.6^{\mathrm{c}}\right)$ & $65.5(58.9)$ & & $91.2(87.7)$ & $94.0(100)$ \\
13 & $45.3(33.4)$ & $72.4(56.5)$ & & $95.3(86.5)$ & $100(100)$ \\
18 & $45.5(33.2)$ & & $70.4(67.3)$ & $86.7(85.4)$ & $95.4(100)$ \\
25 & $31.6(32.8)$ & & $66.4(62.5)$ & $83.4(84.3)$ & $97.6(100)$ \\
30 & $32.2(32.4)$ & & $59.8(59.5)$ & $84.4(83.6)$ & $99.9(100)$ \\
\hline
\end{tabular}

a Temperature values are means $\left( \pm 1^{\circ} \mathrm{C}\right.$, as measured by Hobo temperature loggers) from 12 replicated mini-chambers.

b $\mathrm{RH}$ values are means $( \pm 2.5 \% \mathrm{RH}$, as measured by Hobo RH loggers) from three replicated minichambers containing 6 to 12 detached strawberry leaves each, sampled for a minimum of $72 \mathrm{~h}$ (six lighting and external temperature changes).

c Note presence of transpiring leaves induces deviation from static literature values for axenic conditions $(2,40)$.
Lesion expansion experiments. Nonbiased investigations of lesion expansion involved destructive subsampling from controlled environments over time, subsequent microscopic examination of infected tissue, and computer-assisted image analysis. Thus, repeated measures of the same lesions over time and systematic bias inherent in choice of an individual strawberry host were avoided. Environment was controlled within mini-chambers containing saturated-salt solutions. These minichambers were constructed by cutting plastic 18.9-liter drinking water bottles to create a cylinder closed at one end, which was inverted over a glazed ceramic dinner plate (Fig. 1). Approximately $250 \mathrm{ml}$ of a saturated-salt solution was placed in the trough of the plate. As the space above the solution exceeded 1-liter volume, an internal fan was provided to mix the air above the plants and solutions, as per ASTM standards (2). The fan was made from plastic propellers attached to a $12 \mathrm{~V}$ DC motor (Edmund Scientific Co., Barrington, NJ; manufacturers vary). To support the plants above the reservoir of saturated-salt solution, "egg crate" polystyrene overhead lighting cover $\left(1 \mathrm{~cm}^{2}\right.$ mesh, $1 \mathrm{~cm}$ height $)$ was cut to fit within the chamber. After saturated-salt solutions had been placed in the plate, the egg crate support was set spanning the trough of the plate. Saturatedsalt solutions were replenished as necessary during the experiment.

Glass vials containing $20 \mathrm{ml}$ of water held newly expanded trifoliate leaves cut from 21-day-old transplants of the susceptible strawberry cv. Sunset. Leaves were placed abaxial-surface-up in the inoculation tower, inoculated, then trimmed at the petiole after removal from the tower and inserted into vials. Petioles were supported through Parafilm covering the vials, which limited water loss from the vials. Detached strawberry leaves in glass vials were set upon the support, and the cover cylinder with internal fan was lowered over the platform and sealed around the edges with petroleum jelly.

Heating within these mini-chambers from illumination was countered by placing the chambers in a large controlled environment chamber (Conviron PGR15 or PGV36, Winnipeg, Canada) to maintain constant temperature. The large chambers were programmed to counter the conversion of light to thermal energy by a temperature drop during the 12-h light cycle and reheating during the dark cycle to assure constant temperature in the small chambers. Internal chamber temperatures were monitored by Hobo temperature loggers. The magnitude of the light-induced heating within the small chambers varied across the temperature range studied. Therefore, the programming of the Conviron chambers was customized for each temperature treatment. Temperature in the 12 minichambers within a large chamber was con- 
trolled within $\pm 1^{\circ} \mathrm{C}$, as measured by calibrated Hobo temperature loggers (21).

Assignment of one of four saturated-salt solutions to 3 of the 12 small chambers within a large chamber was random within contiguous chamber area blocks (left, middle, right side), providing three replications of $\mathrm{RH}$ treatment (level) per temperature studied. Choice of salt solutions $(2,40)$ is given in Table 1 . Six to 12 inoculated leaves in vials were placed in each small chamber, allowing regular destructive subsampling over time. To obtain the subsample, the small chamber was opened briefly, the subsample leaf removed, saturated-salt solution replenished if necessary (often every 2 to 3 days for the low RH combinations), and closed. Monitoring by Hobo RH sensors showed the disruption was rapidly compensated for, but an environmental fluctuation of 1 to $45 \mathrm{~min}$ per sampling point is acknowledged. The overall experimental design was balanced, lending itself to analysis of variance as a randomized complete block design with replications as blocks and RH as treatments. Each single-temperature run (single inoculation event maintained for 3 to 8 weeks) was

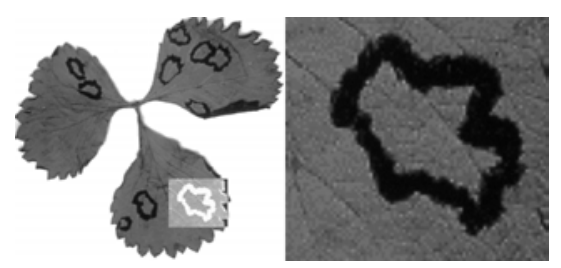

Fig. 2. Marked colony of strawberry powdery mildew caused by Sphaerotheca macularis $\mathrm{f}$. sp. fragariae used for lesion expansion studies. Measure of scanned images followed delineation by microscopic examination of infected tissue.

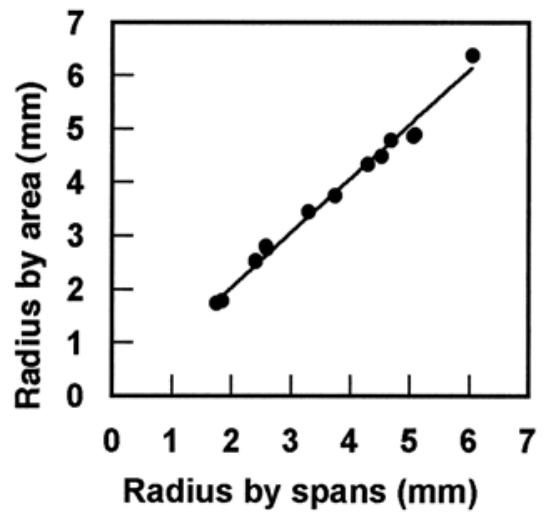

Fig. 3. Validation of radial estimation from area measure of lesions. Area measures were used to determine radii $(=\sqrt{ }[$ lesion area/ $\pi])$. Correlation of these calculated radii to means of the two lesion spans (radius $=[$ longest span + shortest span]/4) was highly significant $\left(r^{2}=0.99\right)$, and also the relationship was linear $(y=1.017 x-$ 0.006 ) and passed through the origin, justifying use of radii derived from area measure as a useful and accurate approximation saving time in this case. analyzed as a balanced completely randomized design of four levels of RH tested at a single temperature with three replications.

Salt solutions provided constant RH. Control of RH (vapor pressure deficit, evapotranspiration) within a small chamber was conducted such that this variable was only investigated at each temperature as a fixed effect, i.e., the Conviron chamber provided one temperature for four levels of RH per experimental run. Extrapolation of findings to response surfaces must acknowledge the experimental conditions were such that the variables of $\mathrm{RH}\left(\mathrm{VP}_{\text {water }}, \mathrm{VPD}\right.$, evapotranspiration) were monitored from a series of experiments conducted at different temperatures. Control of RH was monitored as consistently less than $\pm 2.5 \% \mathrm{RH}$ between the three replicated minichambers within a Conviron chamber, as measured by calibrated Hobo RH loggers (21). Of the salt solutions, water offered the most stable $\mathrm{RH}$ (if not $\mathrm{VP}_{\text {water }}$ ) over the temperature range examined when compared to the typical variability in $\mathrm{RH}$ seen for any given saturated-salt solution used. Sodium chloride provided an extremely stable $75 \% \mathrm{RH}$ over all biologically relevant ranges of temperature, but proved toxic to strawberries in closed systems, apparently due to vapor action (27).

NIH Image program software (versions 1.60-1.61, from the U.S. National Institutes of Health, available online) was used to measure the lesion expansion rate. Individual lesion areas were measured from subsamples collected over time. Detached leaves were removed from chambers, and the perimeters of individual lesions on the abaxial surface were outlined with a high- contrast marker while viewing the leaf under a dissecting microscope (Fig. 2). The area of these marked leaves was measured by image analysis performed on a Macintosh. Images were acquired using a flatbed scanner (Hewlett Packard ScanJet IICX, Palo Alto, CA) and Adobe PhotoShop software (versions 2 to 3.05, Adobe Systems, Inc., San Jose, CA) and saved as 7.87 pixels $/ \mathrm{mm}$ (200 dots per inch) grayscale TIFF (tagged image file format) files. Area measures were calculated back to circularized radii (radius $=$ square root [lesion area divided by $\pi$ ]), and radii were averaged for all measurable distinct lesions $(1 \leq n \leq 31)$ within a subsample. Actual measurements of lengths and widths of these non-isodiametric lesions were regressed on radii calculated from area measures. The correlation between the circularized radius and the means of the two lesion diameters (radius $=[$ longest diameter + shortest diameter]/4) was highly significant and the relationship was linear and passed through the origin, justifying the use of derived radii as a useful and accurate time-saving approximation (Fig. 3). Regressions of data from individual mini-chambers, i.e., 12 regressions per experimental run, were carried out. A value of 0 radial growth at $24 \mathrm{~h}$ was included in the regressions, but the line was not forced through this point so as not to weight one value disproportionately to others. Rate of radial expansion for a treatment (RH level at a constant temperature) was taken from the mean of the three slopes (1 per minichamber replicate) of the linear regressions of these calculated radii over time (Fig. 4). Data from one to four repeated experimental runs $\left(1\right.$ run each at 5 and $30^{\circ} \mathrm{C}, 2$ runs at

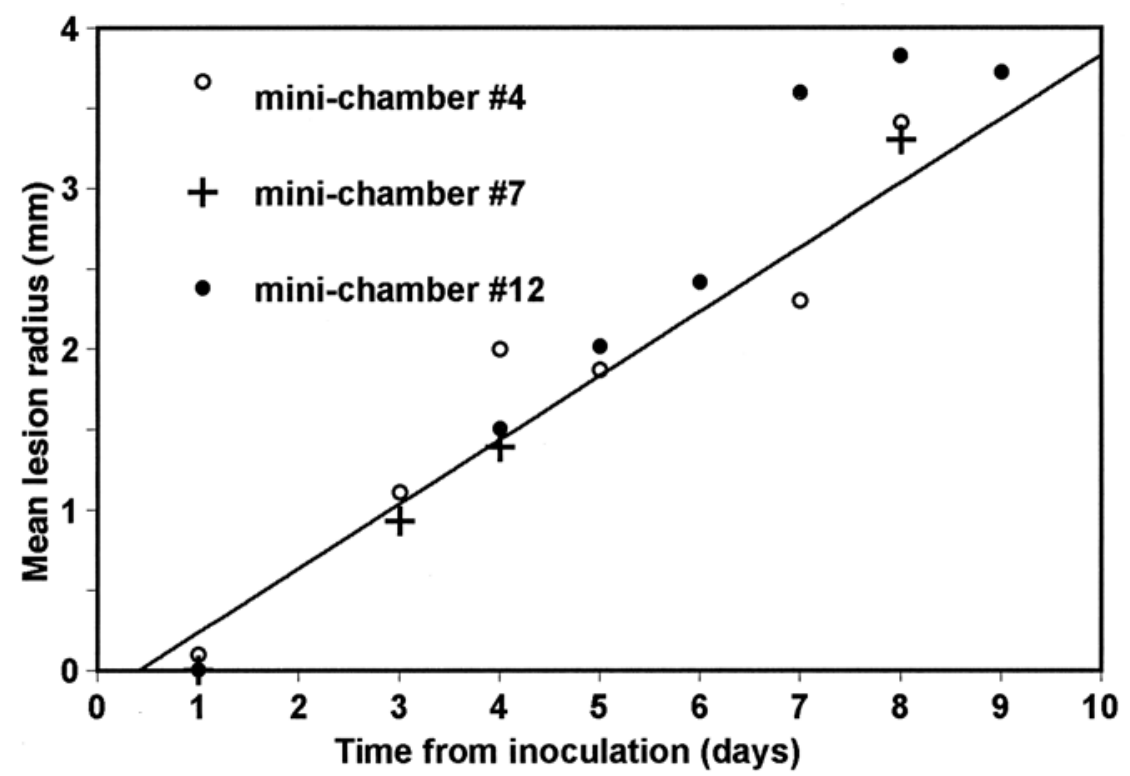

Fig. 4. Lesion expansion rate determination by regression of mean radii at destructive subsamplings over time. The slope (rate) was then used for subsequent analyses to describe effects of different environments upon this rate. Shown is one rate $(0.399 \mathrm{~mm} /$ day $)$ for a single run of $32 \%$ relative humidity $(\mathrm{RH})$ at $25^{\circ} \mathrm{C}\left(y=0.3995 x-0.166, r^{2}=0.91\right)$. Data set from a single run provides four values (RH levels) of lesion growth rate response used in analyses of Table 2 and Figures 6 and 7. 
$13^{\circ} \mathrm{C}, 4$ runs at $18^{\circ} \mathrm{C}$, and 3 runs at $25^{\circ} \mathrm{C}$ ) at each of 20 sampling environments were averaged to generate a response graph. The higher replication numbers over time were chosen to raise the level of confidence in findings, especially in the temperature regions representative of cultural conditions for commercial fruit production in California strawberry fields, which were also near the optimum for growth. Response graphs were derived from $n=1,010$ subsample lesion measures.

Data analysis. Operations on data used equations (regressions, analysis of variance, parameter determinations) from Steel and Torrie (36) programmed into Excel software (Microsoft, versions 6 to 98 , on Macintosh). Data from lesion expansion studies were analyzed as means over the runs, aggregated as described above (i.e., 1 to 4 experimental repeats at each point of surface). To estimate radii of lesions for measure of expansion rates, irregular lesion areas were circularized. Lesion expansion rates were determined by linear regression of measures of derived radii at various intervals ranging from 7 to 30 days. For calculation of vapor pressure of water $\left(\mathrm{VP}_{\text {water }}\right)$ or its deficit (VPD), tabular values (1) were used to derive the equation

$y($ in $\mathrm{mm} \mathrm{Hg})=1.5015\left(10^{-7} T^{5}\right)$

$-8.8886\left(10^{-6} T^{4}\right)+4.9939\left(10^{-4} T^{3}\right)$

$+7.8898\left(10^{-3} T^{2}\right)+0.33755 T+4.5995$

where $y=$ vapor pressure of water at saturation or $100 \% \mathrm{RH}, T=$ temperature ${ }^{\circ} \mathrm{C}$, over the range -3 to $+40^{\circ} \mathrm{C}$. Regressions were performed with Cricket Graph (Version 1.3, Cricket Software, Malvern, PA). Fit was equivalent to

VP $($ in $\mathrm{mm} \mathrm{Hg})=4.6698 e^{0.06241 T}$

after Xu et al. (45). Calculation of VPD (or partial $\mathrm{VP}_{\text {water }}$ ) by either equation was defined as

VPD $($ in $\mathrm{mm} \mathrm{Hg})=\mathrm{VP}[1-(\% \mathrm{RH} / 100)]$

The data were fit to several epidemiological models. Temperature response was described using a Weibull probability density function $(28,39)$ modified after Duthie $(3,7)$ such that response $(y=$ germination $\%$ or $y=$ lesion expansion rate in $\mathrm{mm} /$ day)

$y=E^{\prime}\{\exp [(T-F) G /(H+1)]\} /\{1+\exp [(T$ $-F) G]\}$ where $E^{\prime}=E[(H+1) / H] H^{1 /(H+1)}$

$T$ is temperature ${ }^{\circ} \mathrm{C}, E$ is the maximum response, $F$ is a location parameter proportional to the optimum temperature, $G$ is the intrinsic rate of decline from the response maximum as the temperature deviates from the optimum, and $H$ is the degree of asymmetry of the curve. Best fit parameter values were determined by successive iterations (Levenberg-Marquardt method) of initial parameter estimates using the user-defined curve fitting functions available in the software DeltaGraph (Version 4.5, SPSS Inc., Chicago, IL). Response to $\mathrm{VP}_{\text {water@ 100\%RH }}$ was also modeled following this relation, substituting $x=\mathrm{VP}_{\text {wa- }}$ ter@100\%RH (as calculated in units of mm $\mathrm{Hg}$ ) for $T$. Lesion expansion rate was also modeled using two models suggested by $\mathrm{Xu}$ (41) for the co-generic pathogen of rose S. pannosa var. rosae: one an exponential model and the other a variant of the thermodynamic model. The models are, respectively,

$y_{1}=(A+B T) C^{T}$

$y_{2}=A[(T+273.2) / 298] \exp (B\{1-[298 /$

$(T+273.2)]\}) /[1+\exp (C\{1-[D /(T+$ 273.2)]\})]

where $y_{1}=$ lesion expansion rate in $\mathrm{mm} /$ day and $y_{2}=$ lesion expansion rate in $\mathrm{mm} / \mathrm{h}$, and $A, B, C$, and $D$ are parameters to be estimated. Polynomial models were also generated for some data as alternate interpretations using algorithms of the DeltaGraph software. Parameter and optimum temperature estimates from all models are given in Table 2. All other calculations were performed using Excel software on Macintosh as described above.

\section{RESULTS}

Germination experiments. Review of the percent germination data collected at each point in time showed significant temperature treatment effects had emerged by $6 \mathrm{~h}$ and become highly significant by $20 \mathrm{~h}$, remaining so for the duration of the $288 \mathrm{~h}$ analyzed. The estimated optimum is near $20^{\circ} \mathrm{C}$. This was estimated by fitting the Weibull probability density function model (Fig. 5). Incubation beyond 2 days did not significantly increase measured germination, even when monitored up to $288 \mathrm{~h}$ or 12 days (data not shown). In vitro conidial germination required $100 \%$ RH. Germina- tion was noted at all temperatures tested by $6 \mathrm{~h}$, and reached maximum by $48 \mathrm{~h}$. There was minimal $(<8 \%$ optimal) germination at 4 and $36^{\circ} \mathrm{C}$, the lowest and highest temperatures tested, respectively. Although greatly reduced, germination was observed at $36^{\circ} \mathrm{C}$, a temperature rarely reached in fruiting strawberry fields in California where mildew is observed. Figure 5 shows an apparent shift of optimum germination temperature downward from $27^{\circ} \mathrm{C}$ at $6 \mathrm{~h}$ to $25^{\circ} \mathrm{C}$ at $20 \mathrm{~h}$ to $20^{\circ} \mathrm{C}$ at $48 \mathrm{~h}$. Maximum germination reached by 2 days was best described by Weibull probability density function $(28,39)$ modified after Duthie $(3,7)$ using the parameters given in Table 2 .

Lesion expansion. Each constant temperature run of $4 \mathrm{RH}$ levels was analyzed by ANOVA (RCBD), and treatment effects (RH level) were not found to be significant. Evaluation of lesion expansion rate data across all temperatures indicated temperature and/or saturation water vapor pressure to be the significant variables with highest correlation by several models to lesion expansion rate. Optimal lesion growth conditions were observed at $25^{\circ} \mathrm{C}$. Restricted lesion expansion occurred at $5^{\circ} \mathrm{C}$, the lowest temperature tested, and at $30^{\circ} \mathrm{C}$, but lesions (and detached strawberry leaves) did not persist at $35^{\circ} \mathrm{C}$, the highest temperature tested. Lesions expanded most rapidly at 18 and $25^{\circ} \mathrm{C}$ (Fig. 6A) and/or 7 to $23 \mathrm{~mm} \mathrm{Hg}$ water vapor pressure (Fig. 6B) and/or 0 to $15 \mathrm{~mm} \mathrm{Hg} \mathrm{VPD} \mathrm{(Fig.} \mathrm{6C).}$ Lesion expansion rates for these data were analyzed for fit to several models, given in Table 2 and graphically depicted in Figure 7A to J. As significant RH treatment effects were not detected, data were also

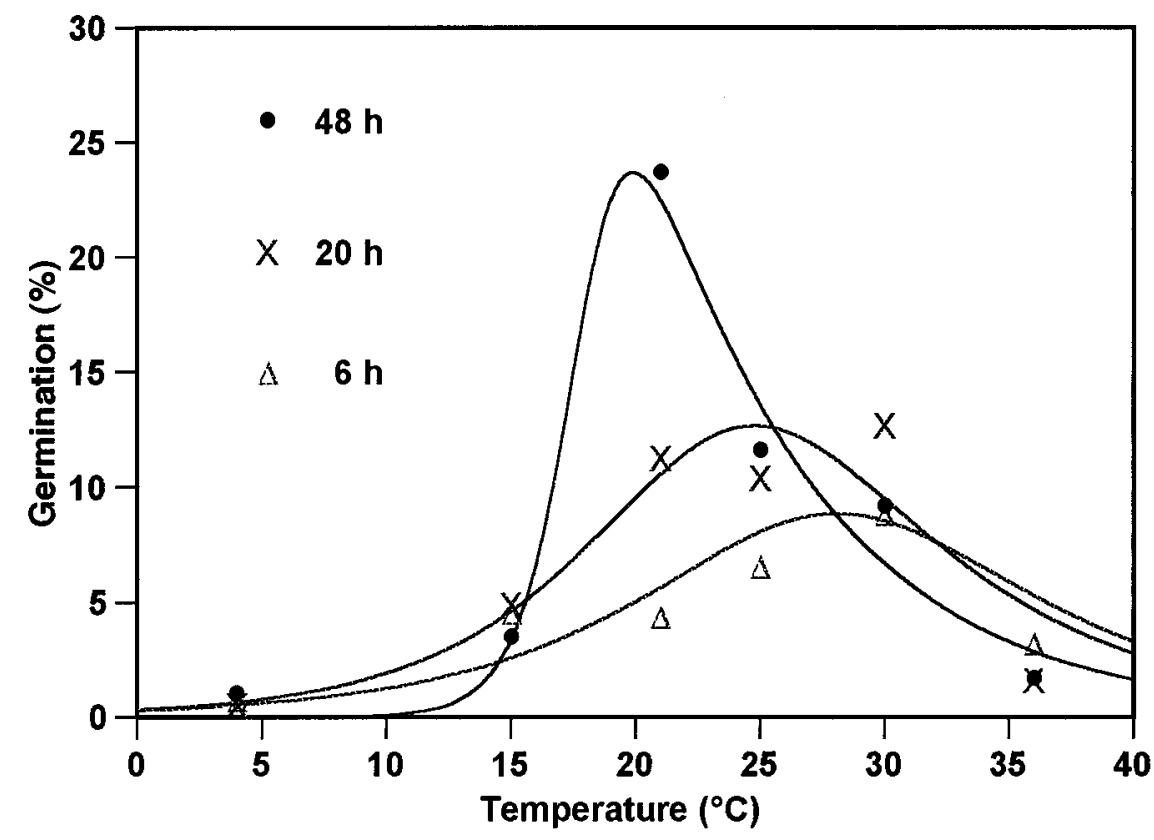

Fig. 5. Weibull probability density distributions describing predicted percent germination of Sphaerotheca macularis f. sp. fragariae conidia on glass slides up to $48 \mathrm{~h}$. Best parameter estimates given (Table 2) for each time. At $6 \mathrm{~h}$, the optimum was $27^{\circ} \mathrm{C}$. By $48 \mathrm{~h}$, this optimum shifted down to $20^{\circ} \mathrm{C}$. 
averaged by temperature without accounting for RH (Fig. 7B). This interpretation suggests a temperature optimum for lesion expansion closer to $25^{\circ} \mathrm{C}$ than the $23^{\circ} \mathrm{C}$ optimum suggested by consideration of the data without averaging (Fig. 7A). Polynomial fits also described the data well as a function of temperature (Table 2) or saturation vapor pressure (not shown). Third and fourth degree fits were highly significant, suggesting $23.5^{\circ} \mathrm{C}$ (Fig. $7 \mathrm{C}$ ) and $25^{\circ} \mathrm{C}$ (Fig. 7D), respectively, as temperature optima for maximal lesion expansion. Application of the exponential model suggested by $\mathrm{Xu}$ (41) gave a highly significant fit with the parameters estimated (Table 2) and suggested $25.5^{\circ} \mathrm{C}$ as the optimum (Fig. 7E). The thermodynamic model variant could also be fit with high significance (Table 2) and suggested a temperature optimum closer to $27^{\circ} \mathrm{C}$ (Fig. 7F).

Lesion expansion rate did not correlate with several factors of weather. $\mathrm{RH}$ showed no simple relation to rate of lesion expansion over the range of natural conditions (Fig. 7G), although optimal expansion rates were observed from 32 to $100 \%$ RH (Fig. 6A). Optimal lesion expansion was seen at most values of $\mathrm{RH}$ in the temperature range between 18 to $25^{\circ} \mathrm{C}$, fol- lowed by a rapid drop in growth rate as temperature increased from 25 to $30^{\circ} \mathrm{C}$. VPD (Figs. 6C, 7H) showed no apparent quantitative relationship to lesion expansion. Similarly, partial pressure exerted by water vapor (Figs. 6B, 7I) displayed no apparent relationship to lesion growth. On the other hand, expansion rate could also be modeled as a function of saturation $\mathrm{VP}_{\text {water@100\%RH }}$ using the Duthie relation substituting $x=\mathrm{VP}_{\text {water@100\%RH }}$ for $T$. Parameter estimates are given for this highly significant fit (Table 2), which if translated back to temperature suggests an optimum at $22^{\circ} \mathrm{C}$.

Table 2. Models used to describe growth and development of Sphaerotheca macularis $\mathrm{f}$. sp. fragariae

\begin{tabular}{|c|c|c|c|c|c|c|}
\hline Depiction & $\begin{array}{l}\text { Response } \\
\text { variable }\end{array}$ & Model type & Independent variable & $\begin{array}{c}\text { Parameter } \\
\text { estimates }\end{array}$ & $\begin{array}{l}\text { Fit and no. of } \\
\text { values used }\end{array}$ & $\begin{array}{c}\text { Estimated } \\
\text { optimum }\end{array}$ \\
\hline \multicolumn{7}{|c|}{ Germination } \\
\hline \multirow[t]{3}{*}{ Figure 5} & $\begin{array}{l}\text { Germination \% } \\
\text { at } 6 \mathrm{~h}\end{array}$ & $\begin{array}{l}\text { Weibull probability density as } \\
\text { modified by Duthie } \\
y=E^{\prime}\{\exp [(T-F) G /(H+1)]\} / \\
\{1+\exp [(T-F) G]\} \\
\text { where } E^{\prime}=E[(H+1) / H] H^{1 /(H+1)}\end{array}$ & $\begin{array}{l}\text { Temperature }\left({ }^{\circ} \mathrm{C}\right) \\
\text { time }(\mathrm{h})\end{array}$ & $\begin{array}{lc}E= & 8.84 \\
F= & 27.8 \\
G= & 0.284 \\
H= & 0.905\end{array}$ & $\begin{array}{l}r^{2}=0.75 \\
n=6 \\
P<0.01\end{array}$ & $27^{\circ} \mathrm{C}$ \\
\hline & $\begin{array}{l}\text { Germination \% } \\
\text { at } 20 \mathrm{~h}\end{array}$ & As above & As above & $\begin{array}{ll}E= & 12.6 \\
F= & 23.8 \\
G= & 0.321 \\
H= & 0.734\end{array}$ & $\begin{array}{l}r^{2}=0.82 \\
n=6 \\
P<0.01\end{array}$ & $25^{\circ} \mathrm{C}$ \\
\hline & $\begin{array}{l}\text { Germination \% } \\
\text { at } 48 \mathrm{~h}\end{array}$ & As above & As above & $\begin{array}{ll}E= & 23.7 \\
F= & 18.0 \\
G= & 0.904 \\
H= & 0.187\end{array}$ & $\begin{array}{l}r^{2}=0.96 \\
n=6 \\
P<0.01\end{array}$ & $20^{\circ} \mathrm{C}$ \\
\hline \multicolumn{7}{|c|}{ Lesion expansion } \\
\hline $\begin{array}{l}\text { Figure } 7 \\
\text { A }\end{array}$ & $\begin{array}{l}\text { Lesion expansion } \\
\text { rate }(\mathrm{mm} / \text { day })\end{array}$ & As above & Temperature $\left({ }^{\circ} \mathrm{C}\right)$ & $\begin{array}{lc}E= & 0.856 \\
F= & 24.0 \\
G= & 1.02 \\
H= & 2.78\end{array}$ & $\begin{array}{l}r^{2}=0.66 \\
n=42 \\
P<0.01\end{array}$ & $23^{\circ} \mathrm{C}$ \\
\hline $\begin{array}{l}\text { Figure } 7 \\
\text { B }\end{array}$ & As above & As above & As above & 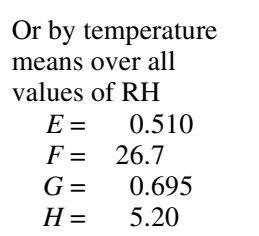 & $\begin{array}{l}r^{2}=0.99 \\
n=5 \\
P<0.01\end{array}$ & $25^{\circ} \mathrm{C}$ \\
\hline $\begin{array}{l}\text { Figure } 7 \\
\mathrm{C}\end{array}$ & As above & $\begin{array}{l}3^{\text {rd }} \text { degree polynomial } \\
y=A x^{3}+B x^{2}+C x+D\end{array}$ & As above & $\begin{array}{lc}A= & -0.000258 \\
B= & 0.0123 \\
C= & -0.148 \\
D= & 0.534\end{array}$ & $\begin{array}{l}r^{2}=0.61 \\
n=42 \\
P<0.01\end{array}$ & $23.5^{\circ} \mathrm{C}$ \\
\hline $\begin{array}{l}\text { Figure } 7 \\
\text { D }\end{array}$ & As above & $\begin{array}{l}4^{\text {th }} \text { degree polynomial } \\
y=A x^{4}+B x^{3}+C x^{2}+D x+E\end{array}$ & As above & $\begin{array}{l}A=-0.0000229 \\
B=0.00143 \\
C=-0.0308 \\
D=-0.282 \\
E=-0.772\end{array}$ & $\begin{array}{l}r^{2}=0.68 \\
n=42 \\
P<0.01\end{array}$ & $25^{\circ} \mathrm{C}$ \\
\hline $\begin{array}{l}\text { Figure } 7 \\
\text { E }\end{array}$ & As above & $\begin{array}{l}\text { Exponential model }{ }^{\mathrm{b}} \\
y=(A+B T) C^{T}\end{array}$ & As above & $\begin{array}{ll}A= & 0.0266 \\
B= & -0.000864 \\
C= & 1.20\end{array}$ & $\begin{array}{l}r^{2}=0.67 \\
n=42 \\
P<0.01\end{array}$ & $25.5^{\circ} \mathrm{C}$ \\
\hline $\begin{array}{l}\text { Figure } 7 \\
\text { F }\end{array}$ & $\begin{array}{l}\text { Lesion expansion } \\
\text { rate }(\mathrm{mm} / \mathrm{h})\end{array}$ & $\begin{array}{l}\text { Thermodynamic model variant }{ }^{\mathrm{b}} \\
y=A[(T+273.2) / 298] \exp (B\{1 \\
-[298 /(T+273.2)]\}) /[1+ \\
\exp (C\{1-[D /(T+273.2)]\})]\end{array}$ & As above & $\begin{array}{l}A=0.02150 \\
B=26.08 \\
C=221.2 \\
D=302.2\end{array}$ & $\begin{array}{l}r^{2}=0.62 \\
n=42 \\
P<0.01\end{array}$ & $27^{\circ} \mathrm{C}$ \\
\hline $\begin{array}{l}\text { Figure } 7 \\
\text { J }\end{array}$ & $\begin{array}{l}\text { Lesion expansion } \\
\text { rate }(\mathrm{mm} / \text { day })\end{array}$ & $\begin{array}{l}\text { Weibull probability density as } \\
\text { modified by Duthiea as above, } \\
\text { substitute } \mathrm{mm} \mathrm{Hg} \text { at } 100 \% \mathrm{RH} \\
\text { for } T\end{array}$ & $\begin{array}{l}\text { Saturation water } \\
\text { vapor pressure } \\
(\mathrm{mm} \mathrm{HG} \text { at } 100 \% \mathrm{RH})\end{array}$ & $\begin{array}{lc}E= & 0.856 \\
F= & 20.92 \\
G= & 0.913 \\
H= & 2.74\end{array}$ & $\begin{array}{l}r^{2}=0.66 \\
n=42 \\
P<0.01\end{array}$ & $\begin{array}{l}20 \mathrm{~mm} \mathrm{Hg} \\
\left(=22^{\circ} \mathrm{C}\right. \\
\text { at } 100 \% \mathrm{RH})\end{array}$ \\
\hline
\end{tabular}

${ }^{a}$ See Carisse et al. (3) and Duthie (7).

${ }^{\mathrm{b}}$ See Xu (41). 


\section{DISCUSSION}

Germination. Evaluation of conidial germination results showed optimal germination temperature near $20^{\circ} \mathrm{C}$ by $48 \mathrm{~h}$ (Fig. 5), confirming earlier reports from England (30) and Canada (16). It was noted that both germination percentage and time required for conidial germination differed from prior reports $(16-18,20,30,31)$. Up to $50 \%$ germination of conidia on glass was reported, with an average of $28 \%$ by Peries (30) in $24 \mathrm{~h}$ at saturated atmosphere. Jhooty and McKeen (16), however, observed up to $90 \%$ potential (see reference) germination on glass within $4 \mathrm{~h}$ at higher than optimal temperatures and $85 \% \mathrm{RH}$. This is difficult to reconcile with results reported simultaneously in another journal by the same authors (17) claiming germination does not occur on glass below $93 \%$ RH. Figure 5 (this study) shows that the highest germination, given similar conditions (i.e., on glass slides at $100 \% \mathrm{RH}$ ) in our studies, never exceeded $25 \%$ even after $48 \mathrm{~h}$. Spore age differences, host, and isolate variability can explain differing results; the former reports from England with strawberry mildew from cv. Coronation, the latter from Canada with mildew from Fragaria ovalis and $F$. chiloensis. Both research groups $(17,30)$ agreed that host leaves as a substrate improved germination percentage and ability to withstand ambient RH less than saturation, presumably due to microclimatic factors. However, their results conflicted with respect to surface wax recognition phenomena. Jhooty and McKeen (18) claimed they were unable to confirm Peries' (31) findings of stimulatory effects of surface waxes upon conidial germination when they attempted to reproduce the experiments.

Valuable findings confirming other studies $(16,20,30)$ emerged despite the conduct of this study of conidial germination in vitro. Notable similarities to several other mildews both off and on hosts were recorded. Maximum germination of conidia was reached by $48 \mathrm{~h}$, which agrees with findings of Taiwanese researchers (20) for S. macularis f. sp. macularis. Similarly, slow germination was recorded in vivo for Oidium sp. of poinsettia (4), and for $S$. fuliginea (14) on sunflower, which required 36 and $48 \mathrm{~h}$, respectively, to reach full germination. Earlier germination and appressorial formation for a large percentage of the conidia have been recorded for most powdery mildew pathogens, including $S$. macularis f. sp. fragariae $(16,30)$.

Another similarity of note for this and other mildews is the apparent cooling shift of optimum germination temperature with later assays in time. This effect is demonstrated for $S$. macularis $\mathrm{f}$. sp. fragariae by comparison of assays at 6,20 , and $48 \mathrm{~h}$, which if taken sequentially show an apparent shift of optimum germination temperature from $27^{\circ} \mathrm{C}$ downward to $25^{\circ} \mathrm{C}$, then $20^{\circ} \mathrm{C}$ (Fig. 5). This same effect has been recorded in vivo for Oidium begoniae on begonia (32) and Podosphaera clandestina on sweet cherry (13). The shift was also recorded by Leu et al. with strawberry powdery mildew in Taiwan, although the shift from 21.1 to $19.7^{\circ} \mathrm{C}$ over $96 \mathrm{~h}$ was less pronounced (20). A normal distribution curve of germination at all temperatures spanning this range, i.e., from roughly 5 to $35^{\circ} \mathrm{C}$, would center near $20^{\circ} \mathrm{C}$. Optimal temperature for earlier germination is warmer than for later germination. One interpretation of these results would be the filling out over time of a normal distribution curve describing germination as a function of temperature. As these results for the strawberry powdery mildew pathogen were obtained in vitro, interaction with host or its factors cannot explain this variation.

Lesion expansion rate. No functional relation examined explained expansion rate of lesions as a function of RH (Fig. 6A), but viewing the same measures of growth rate as a function of temperature and either water vapor pressure or its deficit (Fig. 6B

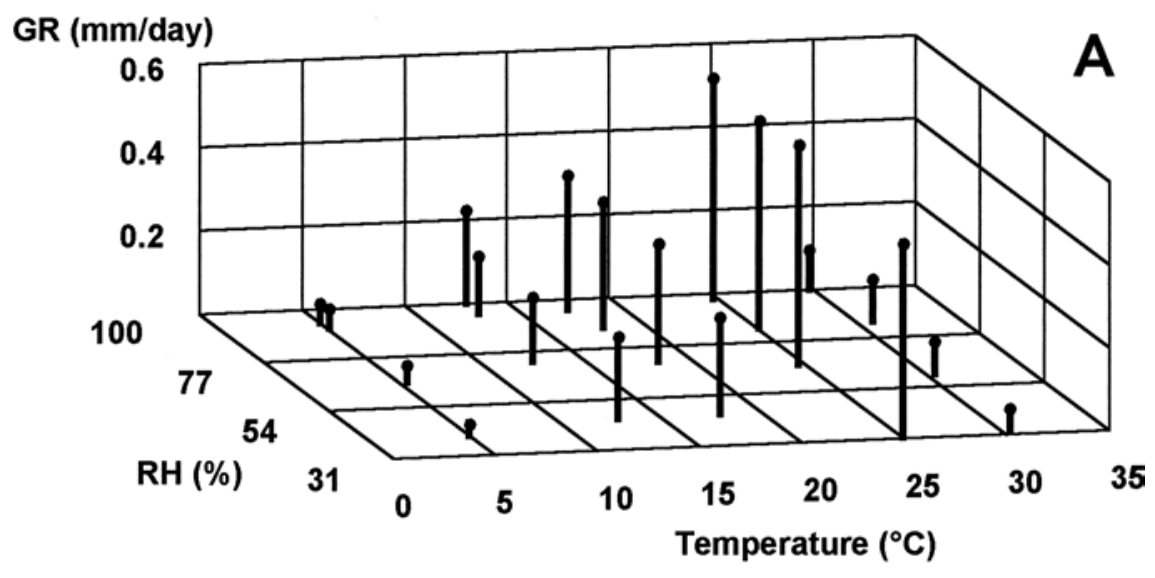

\section{GR (mm/day)}
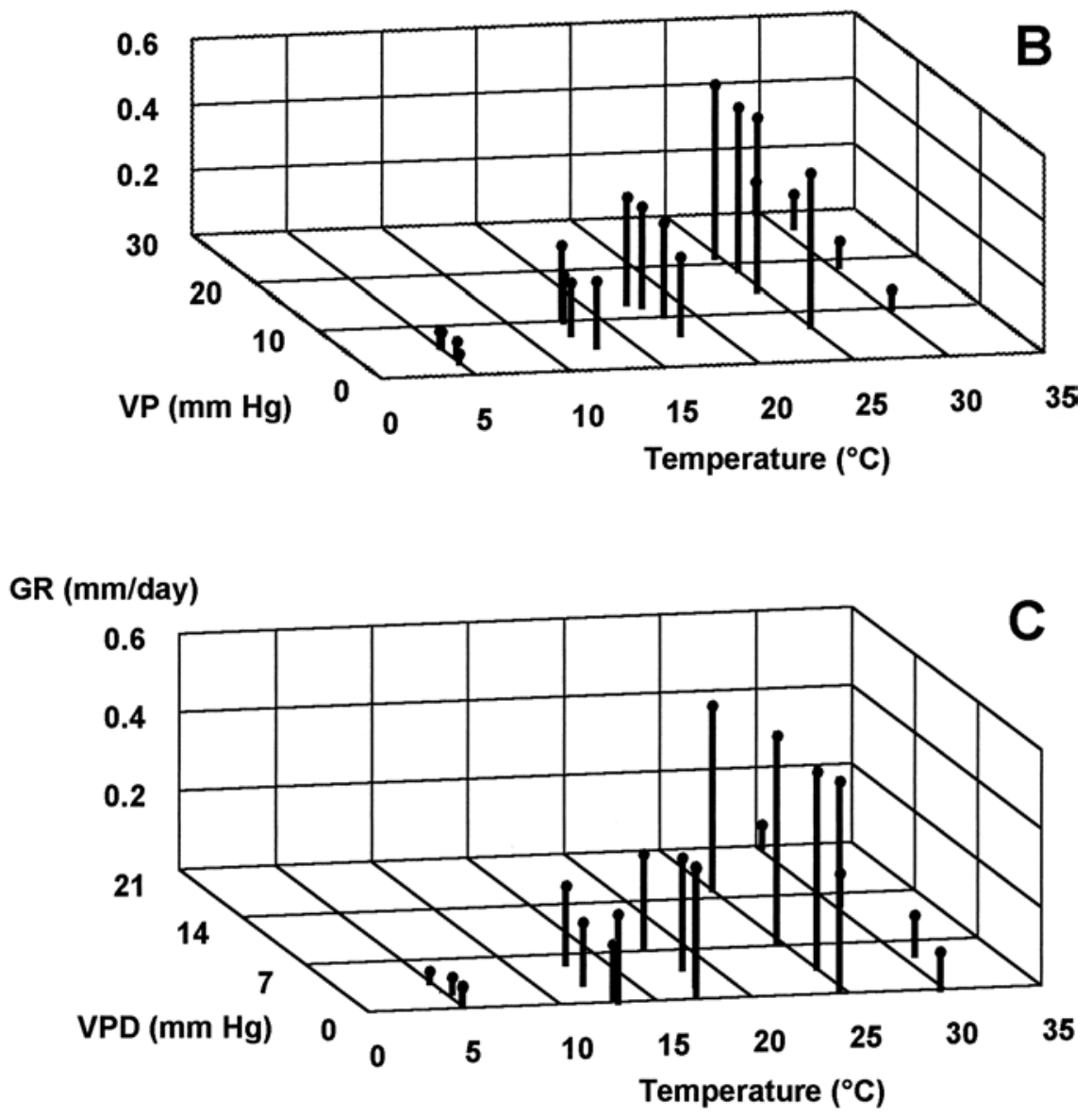

Fig. 6. Response graphs from destructive measure of 1,010 lesions under controlled environments showing growth rate (GR) of strawberry powdery mildew lesion expansion as a function of $\mathbf{A}$, temperature and relative humidity $(\mathrm{RH}), \mathbf{B}$, temperature and ambient water vapor pressure (VP), and $\mathbf{C}$, temperature and vapor pressure deficit (VPD). 
and C) simplifies the visualization(s) in 3 dimensions. The temperature optima again dominate the depictions. Comparisons of VPD values are absolute relations of net flux of water molecules from a surface. This means that a leaf in an environment of $20 \mathrm{~mm} \mathrm{Hg}$ VPD experiences a net loss of water at exactly twice the rate as one in an environment at $10 \mathrm{~mm} \mathrm{Hg} \mathrm{VPD}$, regardless of temperature or $R H$. The distinction of net loss acknowledges that evaporation and condensation occur simultaneously at a surface. Overall, VPD offers little prediction of growth rate. Transects across a 3- dimensional surface described by Figure $6 \mathrm{~A}$ to $\mathrm{C}$ are nearly level along the paths of constant temperature, revealing the superficial relationship of RH, VP, and VPD to lesion expansion. The most significant influence is temperature. These results suggest that water status of the host straw-
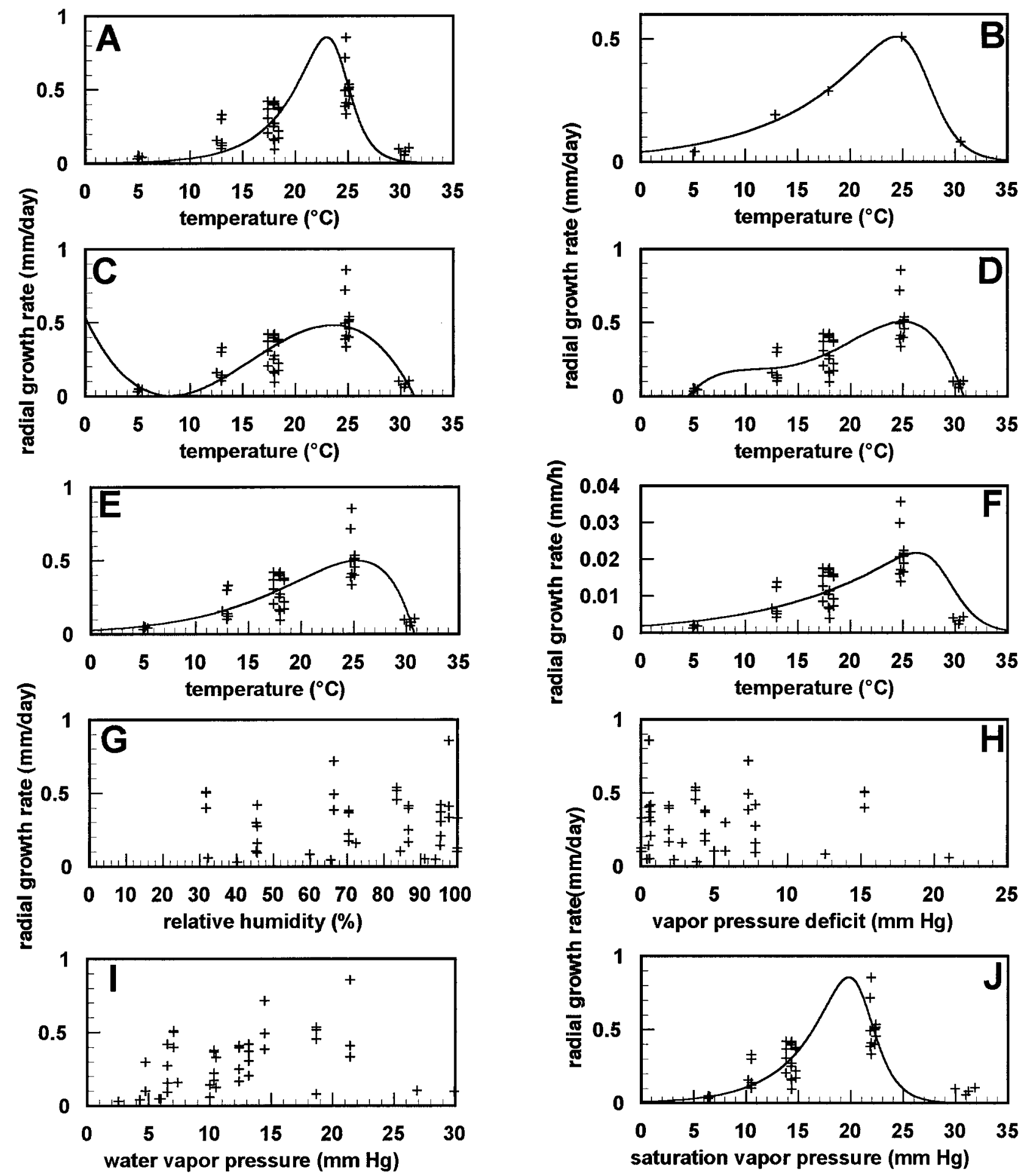

Fig. 7. Comparisons of environmental variables to growth response (lesion expansion rate, $\mathrm{mm} /$ day $\mathrm{or} \mathrm{mm} / \mathrm{h}$ ) of strawberry powdery mildew pathogen Sphaerotheca macularis $\mathrm{f}$. sp. fragariae. Best parameter estimates for equations depicted are given in Table 2. Lesion expansion rate as described by $\mathbf{A}$, Weibull probability density as a function of temperature, $\mathbf{B}$, Same relation and model applied to average responses accumulated by temperature across all relative humidity $(\mathrm{RH})$ values, $n=5, \mathbf{C}$, 3rd degree polynomial as a function of temperature, $\mathbf{D}, 4$ th degree polynomial as a function of temperature, $\mathbf{E}$, exponential model as a function of temperature, and $\mathbf{F}$, variant of thermodynamic model as a function of temperature. Some relationships were lacking, such as the relation of lesion expansion rate and $\mathbf{G}, \mathrm{RH}, \mathbf{H}, \mathrm{VPD}$, and $\mathbf{I}$, ambient water vapor pressure $\mathrm{VP}_{\text {water }} \mathbf{J}$, Weibull model of growth as function of saturation $\mathrm{VP}_{\text {water@100\%RH. }} n=42$ for all panels except $\mathbf{B}$, where $n=5$. Response value of radial lesion expansion given in $\mathrm{mm} /$ day for all panels except $\mathbf{F}$, given in $\mathrm{mm} / \mathrm{h}$. 
berry is of more consequence to $S$. macularis f. sp. fragariae than is atmospheric moisture.

Combining all calculated rates of lesion expansion by temperature without regard to $\mathrm{RH}$ or vapor pressures (RH treatment effects were not found to be significant), the estimated temperature optimum was $25^{\circ} \mathrm{C}$ when the Duthie model was used (Fig. 7B and Table 2). This is rather distant from the temperature showing maximum germination $\left(20^{\circ} \mathrm{C}\right.$, Fig. 5). Without such averaging, the optimum temperature predicted by the Duthie model was $23^{\circ} \mathrm{C}$ (Fig. 7A). This and all other models showed similar predictions of optimal temperatures, which ranged from 22 to $27^{\circ} \mathrm{C}$, slightly higher than the predicted optimum temperature for germination. However, lesion expansion rate as a function of VPD, or evapotranspiration rate, when considered in two dimensions, displayed no apparent relation (Fig. $7 \mathrm{H}$ ), nor did lesion expansion rate as a function of $\mathrm{VP}_{\text {water }}$ (Fig. 7I). Appreciation of the complex roles $\mathrm{VP}_{\text {water }}$ and VPD play are better described in Figure $6 \mathrm{~B}$ and $\mathrm{C}$.

Equivalent temperature response curves describing growth for other mildew pathogens have been found. Xu $(41,42)$ has described $S$. pannosa on rose, and $\mathrm{Xu}$ and Robinson (46) have described P. clandestina on hawthorn with great detail. They described growth rate as a reciprocal relation to latent period with alternate nonlinear models. Temperature profiles for both hawthorn and rose powdery mildew growth show notable similarity to lesion growth profiles of strawberry powdery mildew.

Many claims $(9,19,30,35,37,44)$ of correlative association with powdery mildew epidemiology have been based upon spore trapping data, but few $(5,10,12,13,17,43)$ have manipulated experimental conditions to directly assess conditions of moisture stress (VPD) on phases of the powdery mildew pathogen's biology. Xu and Butt found no trends were detectable in response of $P$. leucotricha colony growth to VPD (43). Grove and Boal (13) also found no effect of VPD after $24 \mathrm{~h}$ on P. clandestina germ tube length, and Grove (12) later found no effect upon latent period from a restricted range of VPD investigations. With the exception of spore germination, the evidence is mounting against VPD as a determinant of growth of the powdery mildew asexual phase. One explanation is that although VPD is independent of temperature, response of an organism to moisture stress may largely be determined by temperature (5).

One can argue that water vapor pressure as a variable is itself a reflection of the temperature effect, but this minimizes the complex interaction of the two factors, which both contribute to symptom expression as measured by rate of lesion expansion. Figure $6 \mathrm{~B}$ suggests that while tem- perature certainly explains a large part of pathogen growth, differences along isothermic transects, for example at $13^{\circ} \mathrm{C}$, reveal a less orderly growth response. Similarly, when considering the lack of effect of $\mathrm{VP}_{\text {water }}$ (Figs. 6B, 7I) or VPD (Figs. 6C, 7H), no simple relation describes undulating transects along the same culturally relevant isotherms. The subtleties of growth response include notation that RH status has a much greater impact on growth at cooler temperatures than at the overall optimum where RH status has virtually no impact. Also, powdery mildew of strawberry fails to thrive at wet but excessively warm conditions. The optima of environmental conditions favoring pathogen growth closely map those promoting host growth and also are the prevailing conditions when epidemic growth is observable in the field (21).

It is difficult to rank the importance of variables of weather this obligate pathogen might encounter at the microclimatic level. Ranking of studied factors' predictive value based on coefficients of determination $\left(r^{2}\right)$ suggested that temperature and saturation water vapor pressure (100\% RH) hold the most promise for modeling pathogen growth. It is curious that the saturation water vapor proved a more weighted variable than did the ambient water vapor pressure measured in the controlled atmospheres the leaves inhabited. Explanations of this observation could include a gradient from saturation at the stomatal aperture grading outward to ambient humidities $(8,17)$, thus effectively providing a saturated atmosphere in the immediate proximity of the leaf surface, where mildew is confined. In sugar beets infected with powdery mildew, failure of stomata to completely close in the dark allowed increased transpiration at low leaf water potentials (induced by soil water stress, not simulated in these present experiments) compared to healthy leaves (11). Another interpretation is that saturation water vapor pressure so closely aligns with temperature that these experiments were not of enough power to resolve the difference. As a single variable, VPD proved of little value without knowledge of the former factors. Thus, it appears the pathogen extracts the water it needs from strawberry even under arid conditions.

In conclusion, growth of $S$. macularis $\mathrm{f}$. sp. fragariae, the powdery mildew pathogen of strawberry, was described as a function of temperature and water vapor pressure relations. Growth was broken down to the phases of germination, lesion expansion, and sporulation, and a steady progress of infection across green tissue was observed to occur under all conditions where the pathogen survived irrespective of visible sporulation. As a note, sporulation was observed at all temperatures at which lesions persisted, i.e., from 5 to $30^{\circ} \mathrm{C}$, but not at $35^{\circ} \mathrm{C}(21)$. Multiple models ade- quately described growth responses with highly significant coefficients of determination.

\section{ACKNOWLEDGMENTS}

We thank the California Strawberry Commission for research support, and also thank the many colleagues who provided helpful comments on this manuscript.

\section{LITERATURE CITED}

1. Anonymous 1986. Vapor pressure of water below $100^{\circ} \mathrm{C}$. Pages D-189-190 in: CRC Handbook of Chemistry and Physics 19861987. R. C. Weast, M. J. Astle, and W. H. Beyer, eds. CRC Press, Boca Raton, FL.

2. Anonymous 1995. Standard practice for maintaining constant relative humidity by means of aqueous solutions. Pages 572-574 in: Annual Book of ASTM Standards. 11.03. American Society of Testing Materials, Philadelphia, PA.

3. Carisse, O., Bourgeois, G., and Duthie, J. A 2000. Influence of temperature and leaf wetness duration on infection of strawberry leaves by Mycosphaerella fragariae. Phytopathology 90:1120-1125.

4. Celio, G. J., and Hausbeck, M. K. 1998. Conidial germination, infection structure formation, and early colony development of powdery mildew on poinsettia. Phytopathology 88:105-113.

5. Delp, C. 1954. Effect of temperature and humidity on the grape powdery mildew fungus. Phytopathology 44:615-626.

6. Dhingra, O. D., and Sinclair, J. B., eds. 1995. Basic Plant Pathology Methods, 2nd ed. CRC Press, Boca Raton, FL.

7. Duthie, J. A. 1997. Models of the response of foliar parasites to the combined effects of temperature and duration of wetness. Phytopathology 87:1088-1095.

8. Frampton, V. L., and Longree, K. 1941. The vapor pressure gradient on a transpiring leaf. Phytopathology 31:1041-1042.

9. Friedrich, S. 1995. Calculation of conidial dispersal of Erysiphe graminis within naturally infected plant canopies using hourly meteorological input parameters. Z. Pflanzenkrankh. Pflanzenschutz 102:337-347.

10. Gadoury, D. M., and Pearson, R. C. 1990. Germination of ascospores and infection of Vitis by Uncinula necator. Phytopathology 80:1198-1203.

11. Gordon, T. R. 1981. The detrimental effects of powdery mildew infection on the photosynthetic capabilities of sugar beet leaves (Beta vulgaris L.). Ph.D. diss. University of California, Davis.

12. Grove, G. G. 1998. Meteorological factors affecting airborne conidia concentrations and the latent period of Podosphaera clandestina on sweet cherry. Plant Dis. 82:741-746.

13. Grove, G. G., and Boal, R. J. 1991. Factors affecting germination of conidia of Podosphaera clandestina on leaves and fruit of sweet cherry. Phytopathology 81:1512-1518.

14. Husain, S. I., and Akram, M. 1995. Effect of temperature and relative humidity on conidial germination and germ tube elongation of Sphaerotheca fuliginea (Schlecht ex Fr.) Poll. on sunflower. Z. Pflanzenkrankh. Pflanzenschutz 102:509-513.

15. Jhooty, J. S., and McKeen, W. E. 1962. The perfect stage of Sphaerotheca macularis on strawberry plants. Plant Dis. Rep. 46:218219.

16. Jhooty, J. S., and McKeen, W. E. 1965. Studies on powdery mildew of strawberries caused by Sphaerotheca macularis. Phytopathology 55:281-285.

17. Jhooty, J. S., and McKeen, W. E. 1965. Water relations of asexual spores of Sphaerotheca 
macularis (Wallr. ex Fr.) Cooke and Erysiphe polygoni Dc. Can. J. Microbiol. 11:531-538.

18. Jhooty, J. S., and McKeen, W. E. 1965. The influence of host leaves on germination of the asexual spores of Sphaerotheca macularis (Wallr. ex Fr.) Cooke. Can. J. Microbiol. 11:539-545.

19. Kalyuzhnyi, Y. V., and Zibtsev, V. M. 1980. Powdery mildew on strawberry in the forest and forest steppe regions of the Ukraine. Biologicheskie Nauki 2:70-75.

20. Leu, L. S., Hsu, Y. H., and Lee, Y. H. 1990. Strawberry powdery mildew and its control in Taiwan. Plant. Prot. Bull. 32:24-32.

21. Miller, T. C. 2000. Studies in the control of the powdery mildew disease of strawberry and of the biology of the fungal pathogen Sphaerotheca macularis f. sp. fragariae. Ph.D. diss. University of California, Davis

22. Miller, T. C., and Gubler, W. D. 1998. Field application of Verticillium lecanii controls Sphaerotheca macularis f. sp. fragariae in California strawberry fruit production. (Abstr.) Phytopathology 88:S63.

23. Miller, T. C., Gubler, W. D., and Laemmlen, F. F. 1999. Evaluation of Verticillium lecanii as a biological control of powdery mildew in California strawberry fruit production, 1998. Biol. Cultural Tests Control Plant Dis. 14:51.

24. Nelson, M. D., and Gubler, W. D. 1995. Evaluation of biological and chemical agents for control of strawberry powdery mildew, Sphaerotheca macularis f. sp. fragariae. (Abstr.) Phytopathology 85:1041.

25. Nelson, M. D., Gubler, W. D., and Shaw, D. V. 1995. Inheritance of powdery mildew resistance in greenhouse-grown versus fieldgrown California strawberry progenies. Phytopathology 85:421-424.

26. Nelson, M. D., Gubler, W. D., and Shaw, D. V. 1996. Relative resistance of 47 strawberry cultivars to powdery mildew in California greenhouse and field environments. Plant Dis. 80:326-328.

27. Opila, R. L., Weschler, C. J., and Schubert, R. 1989. Acidic vapors above saturated salt solutions commonly used for control of humidity. IEEE Trans. Components, Hybrids, Manufacturing Technol. 12:114-120.

28. Pennypacker, S. P., Knoble, H. D., Antle, C. E., and Madden, L. V. 1980. A flexible model for studying plant disease progression. Phytopathology 70:232-235.

29. Peries, O. S. 1961. Overwintering of Sphaerotheca humuli on strawberry plants. Plant Pathol. 10:65-66.

30. Peries, O. S. 1962. Studies on strawberry mildew, caused by Sphaerotheca macularis (Wallr. ex Fries) Jaczewski. I. Biology of the fungus. Ann. Appl. Biol. 50:211-224.

31. Peries, O. S. 1962 . Studies on strawberry mildew, caused by Sphaerotheca macularis (Wallr. ex Fries) Jaczewski. II. Host-parasite relationships on foliage of strawberry varieties. Ann. Appl. Biol. 50:225-233.

32. Quinn, J. A., and Powell, C. C. 1982. Effects of temperature, light, and relative humidity on powdery mildew of begonia. Phytopathology 72:480-484.

33. Reifschneider, F. J. B., and Boiteux, L. S. 1988. A vacuum-operated settling tower for inoculation of powdery mildew fungi. Phytopathology 78:1463-1465.

34. Salmon, E. S. 1900. The strawberry mildew. J. Roy. Hortic. Soc. 25:132-138.

35. Schoeman, M. H., Manicom, B. Q., and Wingfield, M. J. 1995. Epidemiology of powdery mildew on mango blossoms. Plant Dis. 79:524-528.

36. Steel, R. G. D., and Torrie, J. H. 1980. Principles and Procedures of Statistics. 2nd ed. McGraw-Hill, San Francisco.

37. Teodorescu, G. 1988. Investigations of micosis biology, ecology and control on strawberry in Romania. Acta Hortic. 265:569-574.

38. The American Phytopathological Society, Committee on Standardization of Fungicida Tests. 1943. The slide-germination method of evaluating protectant fungicides. Phytopathology 33:627-632.

39. Weibull, W. 1951. A statistical distribution function of wide applicability. J. Appl. Mech. 18:293-297.

40. Winston, P. W., and Bates, D. H. 1960. Saturated solutions for the control of humidity in biological research. Ecology 41:232-237.

41. Xu, X.-M. 1999. Effects of temperature on the length of the incubation period of rose powdery mildew (Sphaerotheca pannosa var. rosae). Eur. J. Plant Pathol. 105:13-21.

42. Xu, X.-M. 1999. Effects of temperature on the latent period of the rose powdery mildew pathogen, Sphaerotheca pannosa. Plant Pathol. 48:662-667.

43. Xu, X.-M., and Butt, D. J. 1998. Effects of temperature and atmospheric moisture on the early growth of apple powdery mildew (Podosphaera leucotricha) colonies. Eur. J. Plant Pathol. 104:133-140.

44. Xu, X.-M., Butt, D. J., and Ridout, M. S 1995. Temporal patterns of airborne conidia of Podosphaera leucotricha, causal agent of apple powdery mildew. Plant Pathol. 44:944 955.

45. Xu, X.-M., Harris, D. C., and Berrie, A. M. 2000. Modeling infection of strawberry flowers by Botrytis cinerea using field data. Phytopathology 90:1367-1374.

46. Xu, X.-M., and Robinson, J. D. 2000. Effects of temperature on the incubation and latent periods of hawthorn powdery mildew (Podosphaera clandestina). Plant Pathol. 49:791797.

47. Yarwood, C. E. 1939. Control of powdery mildews with a water spray. Phytopathology 29:288-290. 